\title{
Effect of Eucalyptus Bund Plantation on Yield of Agricultural Crops and Soil Properties in Semi-Arid Region of India
}

\author{
K.K. Bhardwaj ${ }^{1 *}$, R.S. Dhillon ${ }^{1}$, Sushil Kumari ${ }^{1}$, Vishal Johar ${ }^{1}$, \\ V. Dalal ${ }^{1}$ and S.B. Chavan ${ }^{2}$ \\ ${ }^{1}$ Department of Forestry, CCS Haryana Agricultural University, Hisar-125004, Haryana, India \\ ${ }^{2}$ ICAR-Central Agroforestry Research Institute, Jhansi-284001, U.P., India \\ *Corresponding author
}

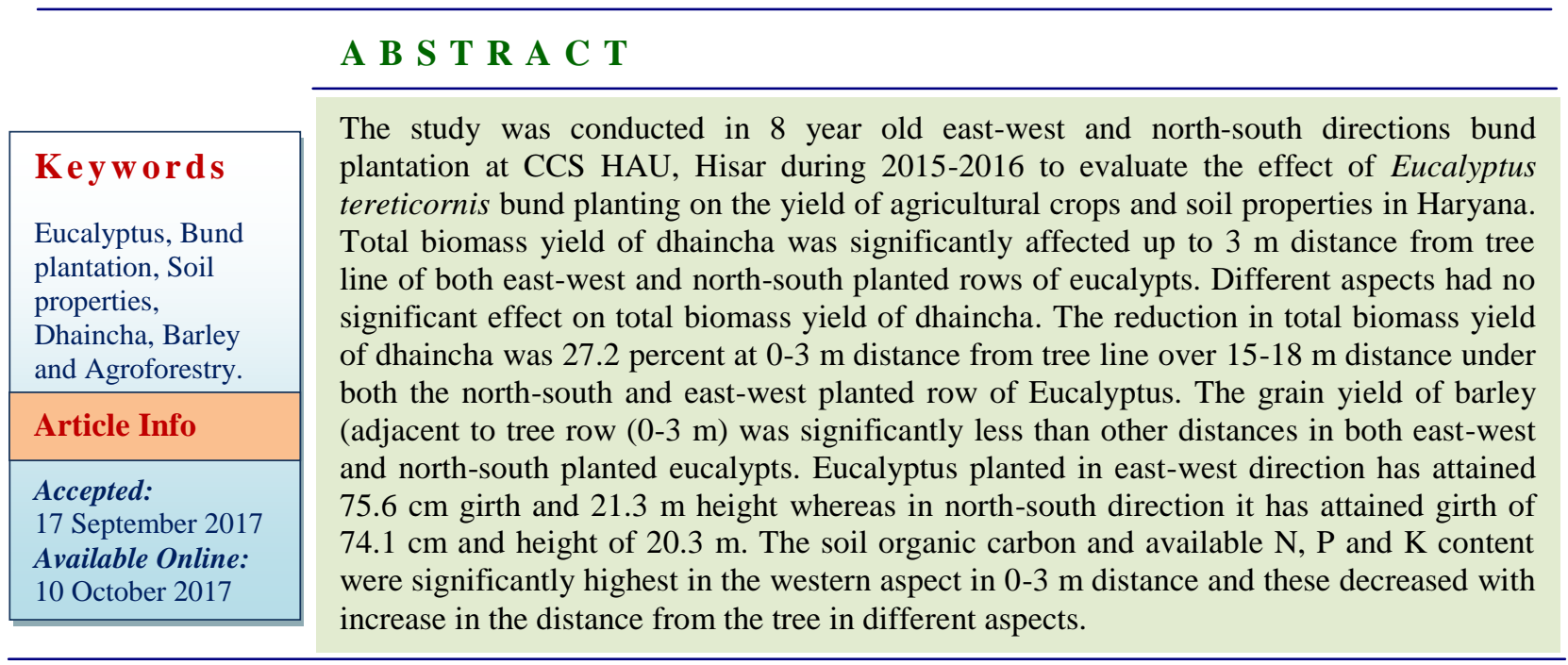

\section{Introduction}

Eucalyptus species was introduced in India to minimize soil erosion, water logging condition, fuelwood and timber demand. Being as fast growing nature, tree has fulfilled the most of the important agroforestry tree species characteristics. Eucalyptus planting in India started taking shape through extension activities of the state forest departments in the late sixties and early seventies. It gradually gained momentum in all parts of India, especially in Punjab, Haryana, western Uttar Pradesh, Gujarat, Tamil Nadu, North Bengal and Andhra Pradesh. Eucalyptus based agroforestry systems widely adopted in the year of 1990-91. The commercial agroforestry systems have changed the scenario of agroforestry in India. This species is providing the opportunity to fulfill the aim of National Agroforestry Policy 2014 of India to achieve 33 per cent of tree cover (NAP, 2014). To accomplish these objectives, the commercial agroforestry systems are prime important and will provide the numerous direct and indirect output (Chavan et al., 2015, 2016). Commercial trees under agroforestry besides providing the tree products, improves soil productivity through ecological and physico-chemical changes 
(Chauhan et al., 2012). Eucalyptus based agroforestry system is most commonly accepted practice in India by the farmers for fulfilling the market demand of plywood, paper, pole and furniture industries. The boundary planting of Eucalyptus is preferred by farmers due to their less interference with agricultural operations. Boundary plantation under agroforestry helps in holding the soil against erosion and improving soil fertility by fixing nitrogen or bringing minerals from deep in the soil and depositing them by leaffall. Such a suitable combination play a vital role in enhancement of better yield productivity, soil nutrient status and microbial population dynamics which plays a major role in nutrient cycling to maintain ecosystem (Raj et al., 2016). Due to shading effect and strong root system of Eucalyptus, which compete for moisture and nutrient with crops resulting grain yield near the tree lines was comparatively low. Boundary plantation of Eucalyptus is very popular in northern India as they are providing extra income to famers with minimum interference with various agricultural operation and crop. Moreover, the small farmers cannot afford to raise block plantation at the cost of agricultural crop yield because the yield reduction ranges from 30-50 $\%$ in block plantation whereas $15-20 \%$ in boundary plantation.

Eucalyptus characteristics of unbrowasble, coppicing, and conical crown shape have a distinct advantage as boundary planting in recommended inter-row spacing and are aligned east-west or north-south direction. In this environment, Eucalyptus boundaries produce a harvestable tree crop within four to five years after planting (Bargalli et al., 1995). The outcome of yield is depends upon tree spacing, density, type and nature of existing bund plantation and their shading effects. Distance from tree base also played significant role on the yield of grain crops. The yield of crops increased with the increase in distance from the boundary tree lines
(Kidanu et al., 2005). Further, as a distance increases the grain yield also increases. In India, wheat (Triticum sp.), chickpea (Cicer arietinum), lentil (Lens esculentum) yields were depressed between 2 and $12 \mathrm{~m}$ from the tree row (Singh and Kohli, 1992) when trees were grown on field boundaries. Similar reduction in yield of intercrop under Eucalyptus has been reported particularly with age of the tree (Singh et al., 1998).

The extent of enrichment in soil properties depends on the tree species, management practices and the quantity and quality of litter and their decay rate Moreover, the leaf litter deposition from Eucalyptus vegetation and resultant soil acidity might also affected intercrop yield. Owing to these negative effects, the positive effects like increased organic matter content from leaf litter decomposition might have resulted in improvement in soil water holding capacity, porosity, texture, essential nutrient and yield improvement of kharif and rabi crop. Eucalyptus plantation results in improvement in soil nutrient ( $\mathrm{N}, \mathrm{P}, \mathrm{K}$, and organic matter) as compared to natural soil (Jan et al., 1996). Eucalyptus plantation can ameliorate salinity and sodicity of soil by improving decreasing soil EC, pH and SAR (Nasim et al., 2007). Therefore, the purpose of this study was to evaluate the effect of different spacings of bund planted Eucalyptus on agricultural crops and soil properties.

\section{Materials and Methods}

The study was conducted in 8 year old Eucalyptus bund plantation of east-west and north-south directions at CCS Haryana Agricultural University, Hisar during 20152016 situated at $29^{\circ} 10^{\prime} \mathrm{N}$ latitude and $75^{\circ} 40^{\prime}$ E longitudes at an elevation of $215 \mathrm{~m}$ above mean sea level. The climate of the experimental site is semi-arid and mainly characterized by a hot summer, a short rainy season and a cold winter. Maximum rainfall is 
received during June to September (monsoon season). The mean annual rainfall is about $650 \mathrm{~mm}$ and the mean annual temperature ranges between $16^{\circ} \mathrm{C}$ and $20^{\circ} \mathrm{C}$. Barley crop (Hordium vulgare) in rabi and dhaincha (Sesbania sesban) in kharif were raised in association with eucalyptus. The treatments consisted of six distances viz. 0-3, 3-6, 6-9, 9$12,12-15$ and $15-18 \mathrm{~m}$ at $3 \mathrm{~m}$ intervals from tree rows upto $18 \mathrm{~m}$. The yield and yield attributing parameters for barley and dhaincha were recorded at different distances from Eucalyptus. Soil samples were collected randomly under different spacings in three replicates from $0-15 \mathrm{~cm}$ depth. The soil samples were taken before sowing of crops and also from control field for the study of various soil chemical properties $(\mathrm{pH}$, electrical conductivity and organic carbon) and available nutrients (nitrogen, phosphorus and potassium). The samples were air dried, ground in a wooden pestle with mortar, passed through a $2 \mathrm{~mm}$ stainless steel sieve and stored for subsequent analysis. The soil $\mathrm{pH}$ and electrical conductivity were determined in soil: distilled water suspension (1:2). The available $\mathrm{N}$ in the soil was determined by alkaline permanganate method (Subbiah and Asija, 1956), organic carbon by partial oxidation method (Walkley and Black, 1934), available $\mathrm{P}$ by sodium bicarbonate method (Olsen et al., 1954) and available K by neutral normal ammonium acetate method (Jackson 1973). The experiment was conducted in randomized block design and data obtained during the course of this investigation, were analyzed by using standard statistical procedure (Panse and Sukhatme, 1989).

\section{Results and Discussion}

\section{Performance of crops with eucalyptus}

Eucalyptus planted in east-west direction had attained $75.6 \mathrm{~cm}$ girth and $21.3 \mathrm{~m}$ height, however, in north-south direction it had attained girth of $74.1 \mathrm{~cm}$ and height of 20.3 $\mathrm{m}$. Total biomass yield of dhaincha was significantly affected up to $3 \mathrm{~m}$ distance from tree line of both east-west and north-south planted rows of Eucalyptus (Table 1). Different aspects had no significant effect on total biomass yield of dhaincha. The visual observations made for barley (Table 2) and dhaincha crop growing with Eucalyptus as boundary plantation revealed that the growth of the crop plants were poor near the tree bases whereas growth were improved as moved towards the tree line in each direction from the centre of the field. The establishment of crop was poor near the tree line. This resulted in overall decline in the barleydhaincha crop yield near the plantation line. In case of boundary plantation, the biomass of crops was found slightly more in east-west direction than north-south direction. The reduction in total biomass yield of dhaincha was 27.2 percent at $0-3 \mathrm{~m}$ distance from tree line over 15-18 $\mathrm{m}$ distance under both the north-south and east-west planted row of Eucalyptus. The grain yield of barley (adjacent to tree row (0-3 m) was significantly less than other distances in both east-west and north-south planted eucalypts (Table 2). However, different aspects had no significant effect on the grain yield of barley. The findings of the study are in line with the Sharma et al., (2007), Chauhan et al., (2012) and Alebachew et al., (2015) in different tree species.

\section{Effect on soil properties}

Generally soils under tree species modifies the nutrient status by adding leaf litter, leachates, chemicals from roots. Boundary plantation had the significant changes in the soil properties. Various soil properties viz $\mathrm{pH}$, electrical conductivity, organic carbon, available $\mathrm{N}, \mathrm{P}$ and $\mathrm{K}$ content was portrayed in Figure 1. Initially the observed value of soil 
$\mathrm{pH}$ and $\mathrm{EC}$ did not differed significantly from different distances from tree line and control in western and eastern aspect. A nominal increase in soil $\mathrm{pH}$ and $\mathrm{EC}$ was observed with increase in distance from tree line. The similar trend was followed in northern and southern aspect. The soil organic carbon and available $\mathrm{N}, \mathrm{P}$ and $\mathrm{K}$ content were significantly higher in the western aspect in 3 $\mathrm{m}$ distance of Eucalyptus tereticornis based agroforestry system whereas, a decreasing trend was observed in average contents of soil organic carbon, $\mathrm{N}, \mathrm{P}$ and $\mathrm{K}$ and organic carbon in agroforestry system with the eastern aspect of Eucalyptus plantation (Fig. 1). Among all the different aspects in various distances organic carbon decreased as the distance from tree was increased. It was 0.54 , $0.50,0.46,0.38,0.34$ and $0.32 \%$ and 0.52 , $0.48,0.44,0.38,0.32,0.30 \%$ for western and eastern aspect respectively. The status of organic carbon, $\mathrm{N}, \mathrm{P}$, and $\mathrm{K}$ were significantly higher in western aspect of $3 \mathrm{~m}$ distance where as it was lowest under control.

Amongst northern and southern aspect, organic carbon content was more in southern aspect at all the distances from tree line of Eucalyptus. As like western and eastern aspect a decreasing trend with the distance from was also observed in northern and western aspect also. Organic matter and available nutrient status of western aspect was highest and it was closely followed by southern aspect. Among all the different aspects the status of organic carbon $(0.54 \%)$, $\mathrm{N}\left(210 \mathrm{~kg} \mathrm{ha}^{-1}\right), \mathrm{P}\left(15 \mathrm{~kg} \mathrm{ha}^{-1}\right)$, and $\mathrm{K}$ (280 $\mathrm{kg} \mathrm{ha}{ }^{-1}$ ) were also significantly higher in western aspect in $3 \mathrm{~m}$ distance where as it was lowest under control (Fig. 1)

Fig.1 Effect of eucalyptus bund plantation on various soil properties

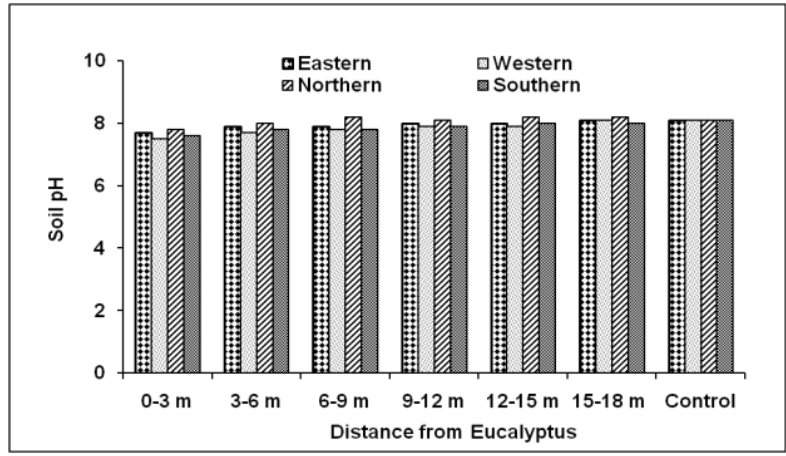

a) Soil $\mathrm{pH}$

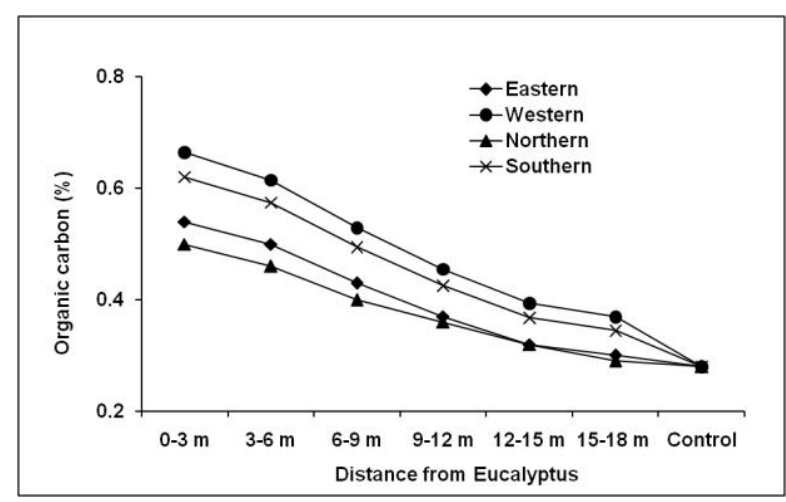

c) Organic carbon

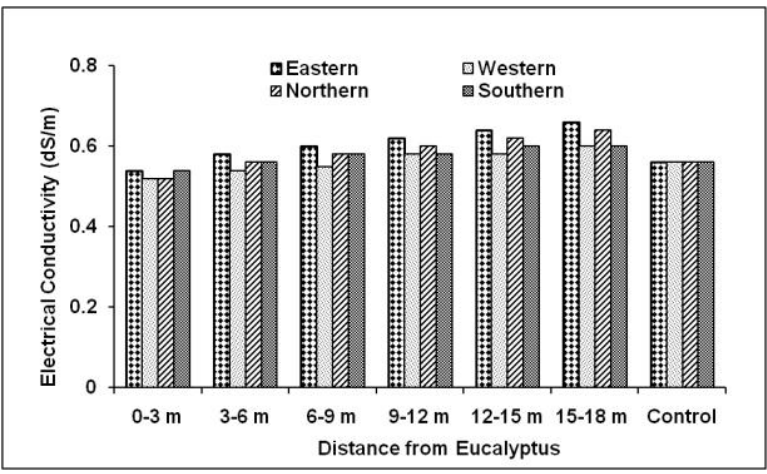

b) Electrical conductivity

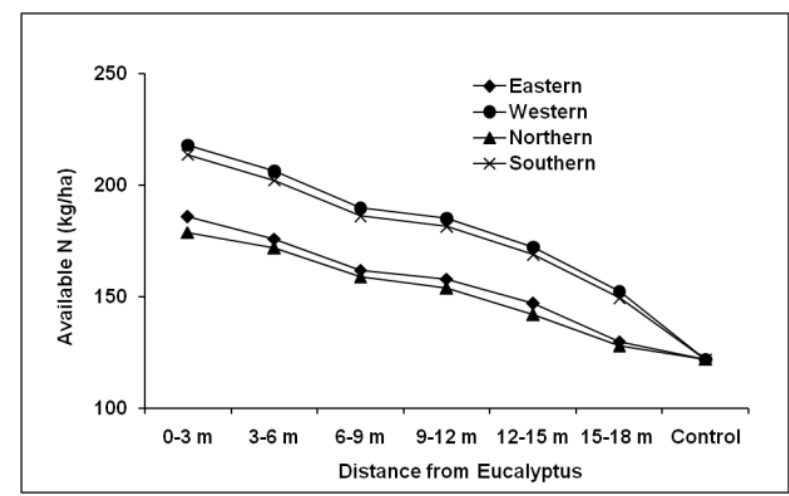

d) Available nitrogen 


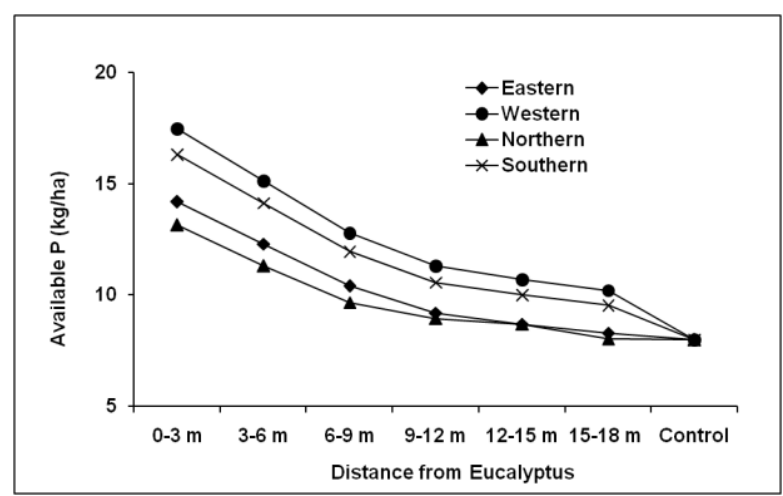

e) Available Phosphorus

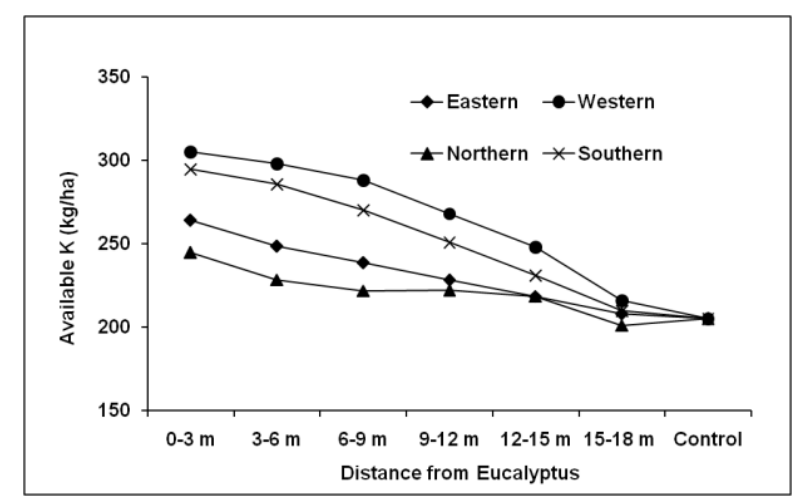

f) Available potassium

Table.1 Effect of row direction and distance from the tree row of bund planted Eucalyptus on yield (t/ha) of dhaincha

\begin{tabular}{|c|c|c|c|c|c|c|}
\hline \multirow{2}{*}{$\begin{array}{c}\text { Tree row } \\
\text { Distance } \\
\text { (m) }\end{array}$} & \multicolumn{3}{|c|}{ East-West Row } & \multicolumn{3}{|c|}{ North-South Row } \\
\hline & $\begin{array}{l}\text { Northern } \\
\text { aspect }\end{array}$ & $\begin{array}{c}\text { Southern } \\
\text { aspect }\end{array}$ & Mean & $\begin{array}{c}\text { Eastern } \\
\text { aspect }\end{array}$ & $\begin{array}{c}\text { Western } \\
\text { Aspect }\end{array}$ & Mean \\
\hline $0-3$ & 6.50 & 6.75 & 6.62 & 6.14 & 6.44 & 6.29 \\
\hline $3-6$ & 8.10 & 8.44 & 8.27 & 7.65 & 8.05 & 7.85 \\
\hline $6-9$ & 8.31 & 8.63 & 8.47 & 7.84 & 8.23 & 8.03 \\
\hline $9-12$ & 8.71 & 8.82 & 8.76 & 8.23 & 8.41 & 8.32 \\
\hline $12-15$ & 8.91 & 9.02 & 8.96 & 8.41 & 8.59 & 8.50 \\
\hline $15-18$ & 9.01 & 9.21 & 9.11 & 8.51 & 8.78 & 8.64 \\
\hline Mean & 8.26 & 8.48 & & 7.79 & 8.08 & \\
\hline \multirow[t]{3}{*}{$\mathrm{CD}$ at $5 \%$} & Distance: & 0.62 & & Distance: & 0.59 & \\
\hline & Aspect: & NS & & Aspect: & NS & \\
\hline & \multicolumn{3}{|c|}{ Distance $\times$ Aspect: NS } & \multicolumn{3}{|c|}{ Distance $\times$ Aspect: NS } \\
\hline
\end{tabular}

Table.2 Effect of row direction and distance from the tree row of bund planted Eucalyptus on grain yield ( $\mathrm{t} / \mathrm{ha}$ ) of barley

\begin{tabular}{ccccccc}
\hline \multirow{2}{*}{$\begin{array}{c}\text { Tree row } \\
\text { Distance } \\
(\mathrm{m})\end{array}$} & \multicolumn{3}{c}{ East-West Row } & \multicolumn{3}{c}{ North-South Row } \\
\cline { 2 - 7 } & aspect & $\begin{array}{c}\text { Southern } \\
\text { aspect }\end{array}$ & Mean & $\begin{array}{c}\text { Eastern } \\
\text { aspect }\end{array}$ & $\begin{array}{c}\text { Western } \\
\text { Aspect }\end{array}$ & Mean \\
\hline $0-3$ & 1.71 & 1.81 & 1.76 & 1.81 & 1.91 & 1.86 \\
$3-6$ & 2.55 & 2.54 & 2.49 & 2.60 & 2.72 & 2.66 \\
$6-9$ & 2.50 & 2.80 & 2.65 & 2.63 & 2.94 & 2.79 \\
$9-12$ & 2.71 & 2.81 & 2.76 & 2.86 & 2.96 & 2.91 \\
$12-15$ & 3.11 & 3.32 & 3.22 & 3.50 & 3.74 & 3.62 \\
$15-18$ & 3.06 & 3.16 & 3.11 & 3.17 & 3.27 & 3.22 \\
Mean & 2.59 & 2.75 & & 2.76 & 2.94 & \\
CD at 5\% & Distance: & 0.24 & & Distance: & 0.27 & \\
& Aspect: & NS & & Aspect: & NS & \\
& Distance $\times$ Aspect: NS & \multicolumn{5}{c}{ Distance $\times$ Aspect: NS } \\
\hline
\end{tabular}


The reduction of soil $\mathrm{pH}$ and $\mathrm{EC}$ closer to tree can be attributed to accumulation and subsequent decomposition of organic matter which releases organic acids (Gupta and Sharma, 2009). The higher nutrient status near the tree might be due to the addition of large quantity of leaf litter. The higher decomposition of leaf litter favours the higher nutrient status of the soil. Similar findings were also observed by Singh and Sharma (2007). Increase in soil carbon through plantations may also act as an important carbon sink. The higher available nutrient content in agroforestry system over the agriculture system may be attributed to litterfall addition from trees as well as addition of root residues of crops and trees. These findings were supported by (Gupta and Sharma, 2009). On account of recycling of organic matter, higher organic carbon and available $\mathrm{N}, \mathrm{P}$ and $\mathrm{K}$ contents were observed in the soil under intercropped eucalyptus plantations than at a site without trees and the contents varied depending upon the intercrops. The impact of agroforestry systems on soil fertility in terms of higher organic matter content, total nitrogen, available phosphorus and potash in the top soil has been reported by Uthappa et al., (2015). Increase in tree litter and nutrients increases with increasing plantation age (Bargali, 1995).

Boundary plantation is prominent feature of Indian agroforestry system as it very popular among the farmers due its less interference, ease in mechanization and demarcation of field boundaries. In present study, the growth of eucalypt trees was better in north-south planted windbreaks but the performance of crop was poor than east-west direction. In case of soil nutrient status, windbreak planted area up to $6 \mathrm{~m}$ away from tree line was significantly more in organic carbon and available macronutrients ( $\mathrm{N}, \mathrm{P}$, and $\mathrm{K}$ ). Thus, Eucalyptus based agroforestry system can sustain the soil health by improving various soil parameters.

\section{References}

Alebachew, M., Amare $\mathrm{T}$ and Wendie $\mathrm{M}$ 2015. Investigation of the effects of Eucalyptus camaldulensis on performance of neighboring crop productivity in Western Amhara, Ethiopia. Open Access Library Journal 2: $1-10$

Bargali, S.S., and Singh S P 1995. Dry matter dynamics, storage and flux of nutrients in an aged eucalypt plantation. Oecologia Montana. 4: 9-14

Chauhan, S.K., Sharma R, Sharma S C, Naveen Gupta and Ritu 2012. Evaluation of poplar (Populus deltoides Bartr. Ex Marsh.) Boundary plantation based agri-silvicultural system for wheat-paddy yield and carbon storage. International Journal of Agriculture and Forestry 2: 239-246

Chavan, S.B., Keerthika A, Handa A K, Ram Newaj and Rajarajan K 2015. National Agroforestry Policy in India: a low hanging fruit. Current Science 108: 1826-1834.

Chavan, S.B., Uthappa A R, Sridhar K B, Keerthika A, Handa A K, Ram Newaj, Naresh Kumar, Dhiraj Kumar and Chaturvedi O P 2016. Trees for life: creating sustainable livelihood in Bundelkhand region of central India. Current Science 111: 994-1003

Gupta, M.K., and Sharma S D 2009. Effect of tree plantation on soil properties, profile morphology and productivity index: poplar in Yamunanagar district of Haryana. Annals of Forestry 17: 43-70.

Jackson, M.L., 1973. Soil chemical analysis. Prentice Hall of India, Pvt. Ltd., New Delhi, 498 p.

Jan, M.N., Dimri B M and Gupta M K 1996. Soil nutrient changes under different 
ages of Eucalyptus monocultures. Indian Forester 122: 55-60.

Kidanu, S., Mamo T and Stroosnijder L 2005. Biomass production of Eucalyptus boundary plantations and their effect on crop productivity on Ethiopian highland Vertisols. Agroforestry Systems 63: 281-290.

Nasim, M., Qureshi R H, Saqib M, Aziz T, Nawaz S, Akhtar J and Anwar-ul-Haq M 2007. Properties of salt affected soil under eucalyptus camaldulensis plantation in field conditions. Pakistan Journal of Agriculture Science 44: 401414.

National Agroforestry Policy 2014. National Agroforestry Policy, Department of Agriculture and Cooperation, Ministry of Agriculture, Government of India pp. $1-13$.

Olsen, S.R., Cole C V, Watanabe F S and Dean L A 1954. Estimation of available phosphorus in soils by extraction with sodium bi-carbonate. United States Department of Agriculture Circular, 939.

Panse, V.C., and Sukhatme P V 1989. Statistical Methods for Agricultural Workers. $4^{\text {th }}$ Edition, ICAR Publication, New Delhi, India.

Raj, A., Jhariya M K and Bargali, S.S., 2016. Bund Based Agroforestry Using Eucalyptus Species: A Review. Current
Agriculture Research Journal 4: 148158

Singh, B., and Sharma K N 2007. Tree growth and nutrient status of soil in a poplar (Populus deltoides Bartr) based agroforestry system in Punjab, India. Agroforestry Systems 70: 125-134.

Singh, B., Singh V, Singh R P and Srivastava B K 1998. Economic prospects of vegetable intercropping in young Eucalypts plantation. Annals of Agricultural Research 19: 470-474

Singh, H.P., Kohli R K and Batish D R 1998. Effect of poplar (Populus deltoides) sheltered on the growth and yield of wheat in Punjab, India. Agroforestry systems 40:207-213.

Subbiah, B.V., and Asija G L 1956. A rapid procedure for the estimation of the available nitrogen in soils. Current Science 25:259-260.

Uthappa, A.R., Chavan S B, Dhyani S K, Handa A K and Ram Newaj 2015. Trees for soil helth and sustainable agriculture. Indian Farming 65: 2-5.

Walkley, A., and Black I A 1934. An examination degtareff method for determining soil organic matter and a proposed modification of the chromic acid titration method. Soil Science 37: 29-37.

\section{How to cite this article:}

Bhardwaj, K.K., R.S. Dhillon, Sushil Kumari, Vishal Johar, V. Dalal and Chavan, S.B. 2017. Effect of Eucalyptus Bund Plantation on Yield of Agricultural Crops and Soil Properties in Semi-Arid Region of India. Int.J.Curr.Microbiol.App.Sci. 6(10): 2059-2065. doi: https://doi.org/10.20546/ijcmas.2017.610.245 